\title{
Contents: London Review of Education 18(3)
}

\section{Special issue: Developing an empowering school curriculum - A renewed focus on action research}

Developing an empowering school curriculum: A renewed focus on action research

Pete Wright

Is there hope for action research in a 'directed profession'?

Caroline Daly, Linda Davidge-Smith, Chris Williams and Catherine Jones

Maintaining an empowered school community: Introducing digital technologies by building digital literacies at Beehive Montessori School

Samantha Owen and Sharon Davies

From peer review to collaborative peer enquiry: Action research for school improvement and leadership development David Godfrey

Cross-school 'close-to-practice' action research, system leadership and local civic partnership re-engineering an inner-city learning community Peter Dudley, Martin Pratt, Christine Gilbert, Jon Abbey, Jean Lang and Helen Bruckdorfer

Exploring teachers' experiences of action research Sinéad Vaughan

Teachers as researchers: Reflecting on the challenges of research-practice partnerships between school and university in Chile Gonzalo R. Guerrero-Hernández and Rocío A. Fernández-Ugalde

Certainty abandoned and some implications for curriculum research Jean McNiff

Dialoguing with teacher-educators, valorizing teacher innovations

Vijaya Sherry Chand, Samvet Kuril and Anurag Shukla

Curriculum design through lesson study

Geoff Wake and Sarah Seleznyov

Close-to-practice research: The need for student voice and the strange case of Academy $x$

Simon Edwards and Chris Brown

Developing motivated adolescent readers and enhancing student voice, using action research in disadvantaged contexts

Tara McMullan and Julia Sutherland

\section{Viewpoints}

Thoughts on whole school inspection post-Covid

Colin Richards

'When black lives matter all lives will matter' - A teacher and three students discuss the BLM movement

Ann Phoenix, Afiya Amesu, Issy Naylor and Kafi Zafar

This is an open-access article distributed under the terms of the Creative Commons Attribution Licence (CC-BY) $4.0 \mathrm{https} / / /$ creativecommons.org/licenses/by/4.0/, which permits unrestricted use, distribution and reproduction in any medium, provided the original author and source are credited. https://doi.org/10.14324/LRE.18.3.00 (e-ISSN: 1474-8479). https://www.uclpress.co.uk/pages/london-review-of-education 


\section{Book reviews}

Facing Challenges and Complexities in Retention of Novice Teachers, edited by Denise McDonald

Jyoti Aggarwal and Eya Mahouachi

Being Modern in China: A Western cultural analysis of modernity, tradition and schooling in China today, by Paul Willis Jingbo Ma

The Rise of Character Education in Britain: Heroes, dragons and the myths of character, by Lee Jerome and Ben Kisby

Hans Svennevig

Understanding Power and Leadership in Higher Education: Tools for institutional change, by Mark Kretovics

Paul Temple 